\title{
Nación, Pueblo e Independencia: el Nacionalismo como Problema en Cataluña
}

\author{
Edgar Straehle ${ }^{1}$
}

Resumen: En este escrito se tiene la intención de profundizar en los diferentes rostros del nacionalismo a partir del conflicto por la independencia en Cataluña. Para ello, se quiere evitar una lectura tanto unívoca como esencialista del nacionalismo. La intención es explorar históricamente y asimismo problematizar en el nivel político los diversos caminos y discursos que han contribuido a la erupción del proyecto independentista catalán en los últimos años. En este contexto, se debe mencionar cómo ciertos intentos de superar el marco nacionalista ayudaron al crecimiento del independentismo. Por ello, prestaré especial atención a la historia (y las limitaciones) de la expresión «un sol poble».

Palabras clave: Nacionalismo, Populismo, Nación, Cataluña, Secesionismo.

\footnotetext{
${ }^{1}$ Universidad de Barcelona edgarstraehle@gmail.com
} 
Abstract: This paper intends to study in depth the different faces of nationalism in connection with the Catalan independence movement. To this purpose, I will try to avoid univocal and essencialist approaches to nationalism. The goal is to explore it from a historical point of view and to problematize from a political perspective the ways and discourses that contributed to the escalation of the Catalan conflict in recent years. In this context, it must be mentioned how certain attempts to go beyond nationalism helped to the growth of independentism. Therefore, I will focus on the history (and limitations) of the expression "un sol poble" (one single people).

Keywords: Nationalism, Populism, Nation, Catalonia, Secessionism.

Resum: En aquest escrit pretenem aprofundir en els diferents rostres del nacionalisme a partir del conflicte per la independència de Catalunya. En fer-ho, volem evitar una lectura unívoca o essencialista del nacionalisme. La intenció és explorar històricament $i$, a més, problematitzar en el pla polític els diferents camins i discursos que han contribuït a l'erupció del projecte independentista català en els últims anys. En aquest context, cal mencionar el fet que determinats intents de superar el marc nacionalista van ajudar al creixement de l'independentisme. Per això, prestarem una atenció especial a la història (i les limitacions) de l'expressió «un sol poble».

Paraules clau: Nacionalisme, Populisme, Nació, Catalunya, Secessionisme. 
Lo peor que se puede hacer con las palabras es rendirse a ellas.

George Orwell

\section{Algunos interrogantes sobre el nacionalismo}

La terrible herencia legada por el totalitarismo nacionalsocialista condujo al desprestigio del nacionalismo y pareció condenarlo a la basura de la historia. A ojos de muchos observadores, se trataba y, de hecho, se trata todavía de una corriente anacrónica, más un indeseable y contumaz remanente del pasado que una alternativa para el presente y menos para el futuro. ${ }^{2} \mathrm{~A}$ partir de la posguerra, por

2 Por eso, un historiador catalán como Josep Termes, en un texto en el que propone cambiar los términos del debate historiográfico en Cataluña, escribirá que «ben sovint alguns historiadors o polítics tendeixen a assimilar tot fet nacional, tota reivindicació nacional, al terme més restringit de "nacionalisme", amb tota la càrrega pejorativa que això pot portar per a aquest moviment atès que es pressuposa que el nacionalisme és burgès, que el nacionalisme és oposat a l'internacionalisme, que el nacionalisme comporta uns nivells de xovinisme i àdhuc de racisme, etc. En tot cas em sembla també que parlar de "fet nacional", de "moviments d'afirmació nacional", és més clar com a concepte, és menys equívoc que no pas "nacionalisme"» (Termes, 1984: 66). Ahora bien, en realidad este giro ya se percibió en los años 30 y se podría retrotraer bastante más allá en el tiempo. De ahí que un historiador nacionalista catalán como Rovira i Virgili (1882-1949) sustituyera el título de su libro El nacionalisme (1916) por El principi de les nacionalitats (1932) porque «en aquests darrers temps s'ha estès en gran manera l'accepció del mot "nacionalisme" en el sentit de xovinisme,

B CLIVATGE, número 7

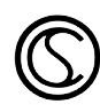


eso, al margen de la extrema derecha, pasó a ser reivindicado en el viejo continente casi únicamente por nacionalismos, no de Estado, sino anticoloniales o secesionistas, los cuales apelaban a derechos como la autodeterminación y a causas como la liberación de los pueblos frente a un Estado represor. En el caso catalán, además, se aducía que su nacionalismo no solo no debía ser confundido con el fascismo, ${ }^{3}$ sino que en realidad había sido una de las víctimas de este, como testimoniaba la ejecución del antiguo presidente de la Generalitat, Lluís Companys (1882-1940), por parte de la dictadura franquista; pero también, y pese a la oposición del Vaticano, de un catalanista de signo conservador y católico como Manuel Carrasco i Formiguera (1890-1938).

Esta imagen actualmente demonizada del nacionalismo, sintetizable en el célebre «le nationalisme, c'est la guerre» de François Mitterrand, contrasta, además de con la misma política nacional emprendida por el presidente francés, con la de los movimientos nacionalistas populares del XIX. Solamente hay que recordar cómo figuras de la importancia de Giuseppe Mazzini (1805-1872), Giuseppe

imperialisme i d'exclusivisme nacional» (1999: 8) y, a lo largo del libro, reemplazará a menudo el término «nacionalista» por el de «nacional». A decir verdad, mucho antes ya encontramos precedentes semejantes. En sus Pensamientos sobre la democracia en Europa, un conocido adalid del nacionalismo ya escribió que «los adversarios de la nacionalidad extraen la definición de esta palabra del pasado. En cambio, deberían buscarla en el futuro, en todos los signos que la preanuncian» (2004: 90-91).

3Para un análisis actualizado de la relación entre el catalanismo y fascismo, véase El catalanisme davant del feixisme (1919-2018), editado por Enric Ucelay, Arnau González i Vilalta y Xosé M. Núñez Seixas (2018).

B CLIVATGE, número 7

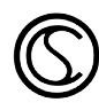


Garibaldi (1807-1882) ${ }^{4}$ o, más tarde, también de un sionista como Bernard Lazare (1865-1903) promovieron un nacionalismo en una clave que se presentaba como revolucionaria e internacionalista. ${ }^{5} \mathrm{~A}$ decir verdad, lejos de ser directamente contrapuestos y mutuamente excluyentes, las relaciones entre el socialismo internacionalista y el nacionalismo no han dejado de ser problemáticas, atravesadas por ambivalencias, tensiones $\mathrm{y}$ momentos de mayor $\mathrm{o}$ menor acercamiento según el contexto espacio-temporal. ${ }^{6} \mathrm{~A}$ menudo, desde

${ }^{4}$ Como han estudiado los historiadores Pere Gabriel y Teresa Abelló, no se debe olvidar la importante influencia de Giuseppe Garibaldi en el seno del obrerismo catalán decimonónico. Recientemente, en su Breve historia del separatismo catalán, Enric Ucelay da Cal ha reinterpretado el proyecto de Francesc Macià como un movimiento de corte neogaribaldiano.

${ }_{5}^{5}$ Por ejemplo, en El nacionalismo judío Bernard Lazare defiende una utopía internacionalista y cuando se pregunta si su nacionalismo judío está en contradicción con el internacionalismo responde: «De ningún modo (...). Cuando los socialistas combaten el nacionalismo, combaten en realidad el proteccionismo y el exclusivismo nacional; combaten ese patriotismo chovinista, estrecho, absurdo, que conduce a los pueblos a ponerse los unos frente a los otros como rivales o adversarios (...) ¿Qué supone ahora el internacionalismo? Supone evidentemente las naciones. ¿Qué significa ser internacionalista? Significa establecer entre las naciones vínculos no de amistad diplomática, sino de fraternidad humana (...). Para que el internacionalismo se establezca, es necesario que los grupos humanos hayan conquistado previamente su autonomía; es necesario que puedan expresarse libremente, es necesario que tengan conciencia de quiénes son» (Lazare, 1898: 12ss).

6 Pensemos en los acercamientos o, directamente, identificaciones de los movimientos de liberación anticolonialista (y no por casualidad en Cataluña no ha habido pocos usos de una retórica anticolonialista frente a lo que consideran que es una ocupación) o también muchos de los movimientos que siguieron o siguen una línea semejante en América Latina. 
la izquierda se ha condenado el nacionalismo por entero, pero en no pocas se lo ha apoyado para casos concretos. Como ejemplo de ello, la II Internacional ya se posicionó a favor de la autodeterminación de los pueblos y en algunas ocasiones, como en el Partido Socialista Francés, se defendieron incluso formas de nacionalismo que se diferenciaran de las étnicas o reaccionarias enarboladas desde la derecha barresiana. En algún caso, como hizo el Comité Central del Partido Comunista Rumano, se llegó a afirmar que «no sólo no hay ninguna contradicción entre los intereses nacionales y los internacionales, sino que hay, por el contrario, una unidad dialéctica plena» (citado por Berlin, 2002: 418).

Domenico Losurdo ha observado que esta misma ambivalencia ante el fenómeno nacionalista se habría plasmado asimismo en la vida y obra de Karl Marx. El pensador italiano arguye que la célebre afirmación de El Manifiesto Comunista de "el obrero no tiene patria» fue seguida de frases en las que se habla de que el proletariado es en sí mismo nacional, que debe convertirse en la clase dirigente de la nación y que debe constituirse a sí mismo como nación. De hecho, su defensa del comunismo se combinó a lo largo de su vida con su apoyo a las luchas nacionales y una actitud favorable a la autodeterminación para casos concretos como el irlandés o el polaco. En opinión de Losurdo, por eso, «la revolución radical invocada por Marx y Engels no solo propugna la liberación/emancipación de la clase oprimida (el proletariado), sino también la liberación/emancipación de las naciones oprimidas» (2014: 16).

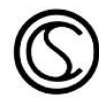


Hace poco, también Mike Davis (2015) ha recuperado este debate $y$, a partir de investigaciones como las de Erica Benner o Kevin B. Anderson, se ha referido al nacionalismo como la «teoría perdida de Marx». Desde luego, con ello no se trata de presentar a Marx como una suerte de defensor del nacionalismo ni nada por el estilo, un extremo insostenible, sino como alguien que, en determinadas coyunturas, no se abstuvo de mostrar un apoyo abierto a determinados movimientos de liberación o defensa nacional. Frente a cierta imagen preconcebida del filósofo alemán, lo que así se reivindica es que Marx no se limitó a entender la política desde un marco única y exclusivamente determinado por las clases sociales. Y al mismo tiempo su ejemplo sirve para advertirnos acerca de la complejidad del nacionalismo.

Por otro lado, el imaginario de la nación pervive hoy en día bajo otros nombres como el de patriotismo, palabra nuevamente de moda gracias a escritos como los de Maurizio Viroli (1997). Desde una óptica parecida, en España, el político Albert Rivera y su formación Ciudadanos han llegado a enarbolar un sedicente patriotismo que dice desmarcarse abierta y claramente del nacionalismo al mismo tiempo, sin embargo, que elude el término «patria» y reivindica a su vez el de «nación». Está claro que el peso histórico de las palabras sigue siendo muy importante en la actualidad.

El problema yace en que no han sido pocas las tentaciones históricas de hacer pasar por patriotismo algo que no es más que 
nacionalismo. ${ }^{7}$ Pensemos sin ir más lejos en los intentos impulsados desde el Partido Popular para apropiarse del patriotismo constitucional de raigambre habermasiana. Y es que tanto esta lectura del patriotismo como la apelación a la Constitución han servido a menudo como recursos discursivos para evitar el recurso a un nacionalismo explícito, así como camuflar lo que eran los intereses nacionales de un Estado que, con frecuencia, se ha opuesto a lo que ha percibido como un proyecto nacional alternativo dentro de su territorio y que ha identificado rápidamente, a veces con demasiada prisa, con un conato de proyecto separatista. ${ }^{8}$

7 Incluso el nacionalista Quim Torra no ha dejado de sentir la tentación de reivindicar el patriotismo en su libro Honorables: «Sentir-se pàtria és sentir-se hereu de la República Catalana, dels valors cívics i ètnics del republicanisme, de l'austeritat, de la virtut civil, de la igualtat, la llibertat i la caritat (entesa com a tenir cura dels béns públics). Sentir-se patriota és entendre el patriotisme com la passió per la llibertat, i per això una pàtria lliure, com diu el professor Viroli, només pot comptar amb la força i l'esperit cívic dels ciutadans desitjosos de ser lliures. Per això el patriotisme civil es contraposa al nacionalisme ètnic. Per això, seguint encara el professor Viroli, el patriotisme no demana una lleialtat cega sinó una lleialtat crítica». Antes, Pujol ya había escrito que «hi ha hagut un concepte de patriotisme que ha ignorat, sistemàticament, que patriotisme vol dir solidaritat, comunitarisme, comunió. El patriotisme hauria de fer por als rics $i$ als poderosos mancats d'esperit de servei i de fraternitat (...). Un patriotisme que no sigui solidaritat i autèntica comunitat, un patriotisme que no signifiqui un esforç autèntic (...), un patriotisme on no es puguin reconèixer els més pobres, els més incultes i els més humils, un patriotisme així no val la pena» (Torra, 2011: 10-11).

${ }^{8}$ Según Ignacio Sánchez Cuenca, «el nacionalismo español de la época democrática es de matriz liberal o constitucional, de inspiración democrática, con algunos elementos histórico-culturales y sin carga xenofóbica alguna. Su punto ciego, sin embargo, reside en su incapacidad para reconocer otras

B CLIVATGE, número 7

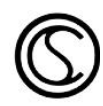


Por ello, lo que se pretende señalar aquí es que el nacionalismo sigue siendo un problema real y muy importante hoy en día. No tanto uno de carácter político contra el que luchar cuanto uno teórico que repensar. Aun cuando muchas personas presenten el nacionalismo como un fenómeno sencillo, homogéneo y anacrónico, y uno más propio del pasado, se trata más bien de uno complejo y plenamente presente. El problema, entonces, ya no es tanto el nacionalismo en singular, como si solo pudiera ser o articularse de una sola manera, sino qué formas diversas puede adoptar este. De ahí que las preguntas a hacerse al respecto no sean pocas.

¿Puede real $\mathrm{u}$ honestamente un movimiento nacionalista afirmar ser de izquierdas e internacionalista o constituye eso una contradicción? ¿Y puede el patriotismo, como ha intentado defender Maurizio Viroli, desmarcarse realmente de ese nacionalismo tan vituperado? ¿Y es viable un proyecto político nacional sin apelar de algún modo a formas de nacionalismo o patriotismo? ¿Hasta qué punto, en especial dentro de un Estado que se entiende como Estadonación, podemos escapar de alguno de los múltiples rostros del nacionalismo? Más controvertido todavía: ¿tiene alguna perspectiva de éxito defender un proyecto en teoría puramente internacionalista

naciones dentro de España. De hecho, lo que unifica y cohesiona el nacionalismo español no son enemigos exteriores, sino el rechazo de las reivindicaciones nacionales que proceden de País Vasco y Cataluña» (Sánchez Cuenca, 2018). Para una profundización en esta cuestión, véase La nación singular de Luisa Elena Delgado. 
o cosmopolita que desatienda la dimensión afectiva hacia lo nacional o nacionalista?

No es sencillo responder a esas preguntas. Para empezar, porque es conveniente precaverse de todo análisis esencialista y por ello generalista de los términos históricos, sin estudiar las diversas materializaciones históricas del nacionalismo. Este, aunque muchos no lo quieran admitir hoy en día, se puede decir de muchas maneras y en cada uno de sus movimientos la cuestión nacional se acompaña de otras demandas políticas: en otras palabras, un movimiento nacionalista no es por lo general algo así como única y exclusivamente nacionalista, de modo que la causa nacional dialoga, intersecciona o queda limitada por otras que la acompañan. Es más, en no pocas ocasiones la apelación a la nación ha servido más bien como una demanda adicional que, según el contexto, podía estar en un primer o segundo plano. De ahí, por ejemplo, que también desde el feminismo, en especial de uno que adopta una perspectiva interseccional, se hayan realizado alegatos en favor de la independencia de Cataluña. ${ }^{9}$ En algunos casos, incluso, la cuestión nacional ha sido la forma de inscribir o potenciar otros tipos de reclamaciones que no eran en modo alguno nacionalistas. ${ }^{10}$ En muchas ocasiones, como también

9Véase, por ejemplo, la antología Terra de ningú. Perspectives feministes sobre la independència (2017).

${ }^{10}$ En especial, por lo que respecta a muchos de sus rostros pasados y por el hecho de hacer residir la soberanía en la nación o en el pueblo, no han sido pocas las posturas que han caracterizado al nacionalismo como un vehículo de democratización. No sin exceso de optimismo, esta ha sido la postura que Dominique Schnapper ha defendido en La comunidad de los ciudadanos («La

B CLIVATGE, número 7

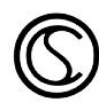


ocurre con la apelación al pueblo de la que luego hablaremos, la invocación a la nación puede ser entendida en una clave más o menos instrumental que adquiere una visibilidad e intensidad mayores en determinadas coyunturas leídas como desfavorables y en las que, frente a un horizonte político poco promisorio, se apela a uno alternativo que sea más ilusionante o, por lo menos, menos malo. A veces se ha hablado por eso del nacionalismo como una utopía de sustitución.

Al mismo tiempo, empero, es difícil contestar los interrogantes mencionados porque, como sucede en no pocos movimientos que apelan al patriotismo, también se puede recaer en un error contrario:

democracia moderna nació bajo forma nacional. La nación moderna, cuya idea surge en Inglaterra a partir del siglo XVI, aparece tras las revoluciones americana y francesa como la organización política legítima y universal. En todos los movimientos nacionalistas de Europa del Este a lo largo de los siglos XIX y XX, y posteriormente en el resto del mundo, la reivindicación de la independencia y de la soberanía nacionales no se separó de la aspiración a la democracia y de la esperanza de la emancipación humana. Hasta la Primera Guerra Mundial, la nación aparecía como el medio de respetar lo verdaderamente humano en el ser humano, es decir su autonomía, simbolizada por los valores de la igualdad y la libertad» (Schnapper, 2001: 15)). Controvertida ha sido la postura que ha defendido la historiadora Leah Greenfeld, quien se ha esforzado en rescatar la importancia histórica del nacionalismo cívico y ha sostenido ideas como que «la atribución de la soberanía al pueblo y el reconocimiento de la igualdad fundamental entre sus diversos estratos, que constituyen la esencia de la idea nacional moderna, son al mismo tiempo los principios básicos de la democracia, que nació con el sentimiento nacional. Ambos conceptos están intrínsecamente vinculados y ninguno de ellos puede entenderse por completo al margen de ese vínculo» (Greenfeld, 2005: 10-11). 
incurrir en un voluntarismo terminológico y defender bajo otro nombre, como si tuviera sentido hablar en términos de un nacionalismo bueno y uno malo, algo que en la práctica se corresponde a lo que siempre se había llamado nacionalismo. Hay que tener en cuenta que la misma defensa del nacionalismo como una forma instrumental puede ser una suerte de estrategia cosmética para excusarlo y evitar que parezca lo que realmente es: un movimiento más identitario y nacionalista de lo que se atreve a confesar(se). Finalmente, se debe tener en cuenta que los anhelos acariciados y formulados desde el pensamiento se han visto traicionados con frecuencia en la práctica. A la hora de la verdad, la apelación a lo nacional o identitario, gracias a la capacidad de movilización que provee, ha supuesto una tentación demasiado atractiva como para desecharla. Y una tentación que, como de costumbre, una vez que se intenta llevar a cabo no siempre es tan sencilla de controlar y puede desbordarse con facilidad. Por ejemplo, cuando aumenta la intensidad de un conflicto, se polarizan las posiciones, se vuelven más agresivas incluso, y eso permite que los rasgos menos moderados y más dogmáticos puedan salir a escena, en buena medida porque las actitudes más nacionalistas de ambos bandos se retroalimentan y se justifican desde el comportamiento y las palabras del adversario. De este modo, lo que en un principio pudo ser una actitud minoritaria injustificable para la mayoría de integrantes de un bando pasa a tener mayor predicamento y pierde el miedo a poderse mostrar sin muchos problemas en público.

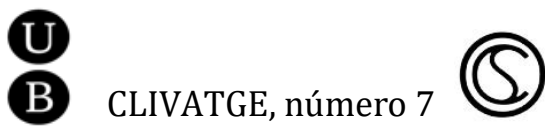


Eso entronca lo que podríamos denominar la paradoja del enfrentamiento: a menudo los bandos antagónicos no dejan de mimetizarse de una manera consciente o inconsciente, voluntaria o involuntaria, por lo que cuanto más enconadas son las posiciones más pueden parecerse en el fondo. De ahí que, como en el caso catalán, sendos bandos hayan justificado en no pocas ocasiones su nacionalismo por el nacionalismo rival. Y, en el nivel fáctico, es cierto que eso ocurre. Otra cosa es que ese nacionalismo emergente no existiera antes en un estado de latencia o adormecido. Es cuando la nación se siente amenazada cuando despierta sus rasgos más propia $\mathrm{y}$ acendradamente nacionalistas. $\mathrm{Y}$ el problema del nacionalismo banal es que, aunque parezca ser inofensivo e incluso no nacionalista en las situaciones de normalidad, es en las de excepción cuando deja de ser banal y adopta un rostro menos agradable. Jorge Cagiao señala acerca de este nacionalismo que:

En realidad, su banalidad es su fortaleza, que consiste en que los individuos hagan y piensen, en determinadas circunstancias, lo que el Estado espera de ellos, sin necesidad de darles órdenes ni instrucciones. No hay autoridad más fuerte que aquella que es capaz de obtener obediencia sin necesidad de ordenar nada (Cagiao, 2018: 21).

De algún modo u otro, en mayor o menor intensidad, todos estos elementos han estado presentes en el conflicto catalán, en el cual la palabra «nacionalismo» ha sido una de las más repetidas. Ahora bien, por lo general lo ha sido de manera interesada y no tanto con el

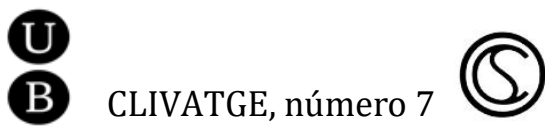


propósito de comprender lo que sucedía, sino para condenar al adversario, especialmente el secesionista. De ahí que haya sido mayormente esgrimida como insulto y como denuncia, como algo de lo que se prefería tachar al bando contrario y no admitir en modo alguno en el propio. Además, buena parte de estas invocaciones al nacionalismo en la arena mediática se han basado justamente en un análisis esencialista y rotundamente negativo del término, como si solo se lo pudiera articular de una manera posible y donde calificar al rival de nacionalista parecía presuponer que el bando en el que uno se incluía no incurriera en lo mismo. ${ }^{11}$ Parecía que los auténticos nacionalistas - esto es, los peores - fueran siempre los otros y que el nacionalismo del antagonista fuese el verdadero causante del conflicto político. De forma paradójica, se ha aducido también que el origen y la culpa de los resabios nacionalistas que pudiera haber en el propio bando se explicarían por la actitud o la agresión del otro contendiente.

De todos modos, ha habido excepciones a esta actitud antinacionalista. Como es lógico, se han dado en mayor número entre los partidarios de la independencia de Cataluña, pues el nacionalismo secesionista teme menos ser incluido en esta etiqueta, pero también las hallamos en el otro lado. Por ejemplo, en alguien declaradamente antinacionalista como Fernando Savater, quien en Contra el

\footnotetext{
${ }_{11}$ Por ejemplo, Félix Ovejero ha escrito en La seducción de la frontera: «En el fondo, todos los nacionalismos son iguales. En el fondo y en la superficie. Algo que, por cierto, solo se puede sostener en serio si se contempla la posibilidad de pensar desde fuera del nacionalismo» (2016: 24).
}

B CLIVATGE, número 7

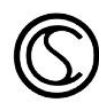


separatismo ha escrito que «el nacionalismo es un narcisismo colectivo que puede ser leve y hasta simpático (amén de inevitable: en este grado menor, creo que toda persona mentalmente sana es nacionalista)». ${ }^{12} \mathrm{Su}$ problema ya no es tanto el nacionalismo en sí cuanto una versión más extrema. Un nacionalismo light, quizá una suerte de evocación supuestamente inocua del nacionalismo banal de Michael Billig, no sería ofensivo ni criticable. La alternativa, de hecho, podría ser peor.

La recuperación de esta visión del nacionalismo, desde distintas perspectivas y tonalidades, también ha sido recorrida por otros pensadores actuales, tales como Fernando García de Cortázar, 13 Edurne Uriarte (2003) o Helena Béjar. ${ }^{14}$ Por supuesto, también el

${ }^{12}$ En cambio, en Contra las patrias, había escrito que «quien a estas alturas del siglo XX no tiembla aún al oír la palabra "nacionalismo" carece de la mínima sensibilidad histórica y nada aprendió de los dramas sangrientos vividos en los últimos ochenta años» (Savater, 1985: 102).

${ }^{13}$ En su reciente libro España, entre la rabia y la idea (2018) ha reivindicado la recuperación del nacionalismo: «El grave problema que ahora estamos sufriendo es que durante estos últimos cuarenta años no se han hecho esfuerzos para nacionalizar España y superar la pobre condición casi exclusivamente administrativa de nuestra patria. No ha sido la norma jurídica lo que nos ha faltado, no ha sido un orden legal el que tanta gente ha echado de menos. Ha sido el sentimiento gozoso de compartir un proyecto que merece ser vivido por todos en el seno de una misma nación, las ganas de existir socialmente como españoles».

${ }^{14}$ En La dejación de España ha escrito: «Es preciso, en mi opinión, reconstruir la tradición del nacionalismo liberal español y afirmar sin sonrojo, y sin temor a ser tachados de políticamente incorrectos, el valor sentimental de España como nación» (Béjar, 2008: 267). 
antiguo presidente del gobierno José María Aznar, quien reivindicó el sentir «orgullo de ser español» y destacó en sus Cartas a un joven español que «el descreimiento en la nación supone una doble disolución: la desintegración nacional y la degeneración democrática» (Aznar, 2007: 79). Además, estos ejemplos no se circunscriben únicamente a España: incluso un pensador liberal como Richard Rorty ha sostenido unas ideas semejantes en Forjar nuestro país. ${ }^{15}$

En este contexto las preguntas a responder serían las siguientes: ¿Acaso no puede uno sentir raíces y sentir orgullo por su cultura o lugar de origen? Y, volviendo al tema que nos ocupa, se podría agregar ¿es forzoso retratar el independentismo catalán sola y exclusivamente como un movimiento nacionalista? En caso afirmativo, ¿habría sido el nacionalismo siempre semejante a lo largo de la historia? ¿Y de cuántos o qué tipos de nacionalismos estaríamos hablando entonces? Por último, frente a lo afirmado por Étienne Balibar (1991), ¿puede el nacionalismo escapar del racismo o la xenofobia, sean directos o indirectos?

\section{Cataluña y las oscilaciones del doble patriotismo}

15 «El orgullo nacional es para los países lo que la autoestima para los individuos: una condición necesaria para la autorrealización. Un exceso de orgullo nacional puede generar belicosidad e imperialismo igual que demasiada autoestima puede producir arrogancia. Pero igual que una autoestima demasiado baja le hace difícil a una persona demostrar su coraje moral, un insuficiente orgullo nacional no favorece un debate contundente y real sobre la política nacional» (Rorty, 1999: 19). 
Para empezar, es preciso recordar que, en Cataluña, el nacionalismo es y ha sido una cuestión central desde hace mucho tiempo y que ha estado representado por personas muy significativasy suficientemente conocidas de su historia política como Enric Prat de la Riba (1870-1917), Francesc Macià (1859-1933), Lluís Companys, Jordi Pujol (1930) o, ahora, Quim Torra (1962). En cambio, el problema de la independencia es mucho más reciente en tanto que un problema de primer orden y una posibilidad sentida como real. Pese a que el Estado catalán fuese infructuosamente proclamado en el pasado hasta en un total de tres ocasiones (en 1934 por Companys; en 1931 por Macià, y ya en 1873 por Baldomero Lostau [1846-1896]), en ninguna de ellas fue con una motivación secesionista, pues la declaración de ese Estado se encuadró y proclamó explícitamente dentro de un marco federal español. 16

Por otro lado, conviene no olvidar que, según las encuestas, en 2006, justo antes de la aprobación del Estatut de Cataluña, los partidarios de la independencia en Cataluña no constituían más que un escaso 13\% según el Centre d'Estudis i Opinió (los votantes de ERC ya superaban el $14 \%$ de votos y sumados a los de CIU agrupaban un

\footnotetext{
16 Otra cosa es, por supuesto, que sí que hubiera defensores de la independencia en esas proclamaciones, especialmente en 1931 y en 1934. Por ejemplo, la postura adoptada por Macià en 1931 fue sentida por muchos nacionalistas como una traición, como los que pasaron a formar parte de la agrupación radical Nosaltres sols! Para una aproximación a las complejidades internas del nacionalismo catalán en los años 30, véase La Catalunya populista de Enric Ucelay da Cal.
} 
45\%).17 Es decir, según estos datos, la mayoría de los partidarios de la independencia serían unos "conversos» recientes a la causa y su número se habría prácticamente cuadruplicado en menos de diez años. Por supuesto, eso no excluye que no fueran nacionalistas antes o que hubieran estado decididamente en contra de la independencia - en ocasiones se apunta que entonces el independentismo estaba en un estado de latencia-, pero sí que implica que su nacionalismo no era incompatible con al menos lo que podríamos llamar una coexistencia o una «conllevancia» con España. Estos datos evidencian asimismo que ese rápido incremento de apoyos a la independencia no solo se explica por el relevo generacional apuntado por Oriol Bartomeus (2018).

Además, se debe apuntar que, no hace más de un año y medio, solo un $12,7 \%$ de los habitantes de Cataluña afirmaba que no se sentían en absoluto españoles. Como era de prever, tras el otoño caliente del pasado 2017 se ha generado una suerte de ruptura emocional por parte de mucha gente y ese porcentaje no ha dejado de incrementarse y en 2018 ha ascendido hasta el 25,3\%. Por esa razón, hay que decir que el independentismo catalán se caracteriza por el hecho paradójico y poco analizado de estar protagonizado, y en especial haberlo estado hasta hace poco, por un buen número de personas que, en el nivel afectivo, se sentían en parte pertenecientes

\footnotetext{
${ }^{17}$ Para consultar las encuestas del Centre d'Estudis i d'Opinió, véase http://ceo.gencat.cat/ca/barometre/.
} 
o vinculados al país del cual se querían separar. ¿Cómo se combina este hecho con las tesis clásicas sobre el nacionalismo?

Para abordar esta cuestión, puede ser útil rescatar la obra Cultura nacional en una sociedad dividida, de Josep Maria Fradera. En ese libro se sostiene la tesis de que lo que existía en la Cataluña de mediados del XIX entre los creadores del nacionalismo catalán donde destaca el rol de Manuel Milà i Fontanals (1818-1889), por cierto el conocido maestro del nacionalista español Marcelino Menéndez Pelayo (1856-1912) - era lo que este historiador denominó una doble fidelidad o doble patriotismo. ${ }^{18}$ Esto se comprobaría en particular en episodios como la Campaña de Marruecos de 1859-1860, donde los regionalistas catalanes colaboraron de manera entusiasta con el resto de españoles. De hecho, como ha estudiado Joan Lluís Marfany (2017), los considerados padres de la Renaixença catalana fueron personas que se sintieron españoles y además contribuyeron a la propagación del nacionalismo liberal español del XIX.

La actitud de este doble patriotismo, expresión que, aun sugerente, no deja de ser problemática, se sintetizaba en el mantra «España es la nación y Cataluña la patria». En 1868, por ejemplo, Víctor Balaguer (1824-1901) ya avanzó la idea de plurinacionalidad y

\footnotetext{
18 Como ejemplo de ello, se puede recordar lo que Joan Cortada (1805-1868) escribe en Cataluña y los catalanes (1860): «Los catalanes, como súbditos de la corona de España, consideran a los demás españoles como a hermanos, y su único anhelo es ver grande y poderosa la patria común, para lo cual nunca dejarán de contribuir con todo el esfuerzo de que son capaces» (1860: 61-62).
}

B CLIVATGE, número 7

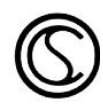


comentó que España es una gran nación formada por varias nacionalidades - recordemos la importancia entonces de la obra Las nacionalidades, de Pi y Margall (1824-1901)—. Más adelante, en 1889, un joven Lluís Duran i Ventosa (1870-1954), y en 1890 Sebastià Farnés (1854-1934), difundieron la idea, ampliamente recogida a lo largo del siglo XX e incluso del XXI, de que para los catalanes España es el Estado y Cataluña la nación (Claret y Santirso, 2014: 95). Más tarde, Enric Prat de la Riba, en La nacionalitat catalana, defenderá que cada nación o nacionalidad (él emplea sendas palabras de manera indistinta) debe tener su Estado y desde esta línea reivindicará un Estado catalán que se enmarque dentro de una federación española. ${ }^{19}$

El significado de estos cambios es bastante claro y ayuda a entender las oscilaciones y el desarrollo de una disimetría interna en este ideal del doble patriotismo. Ahora bien, también se puede añadir que, bajo un rostro sensiblemente distinto, este patriotismo dual también puede ser proyectado hacia más adelante y se torna más evidente en un siglo XX marcado en Cataluña por las grandes oleadas migratorias provenientes del resto de España. Durante el franquismo, por ejemplo, más de un millón y medio de personas arribaron a Cataluña y hoy en día se estima que en torno al 70\% de catalanes tienen padres o abuelos no catalanes. Como ha remarcado Félix

19 En este sentido añade: «Aixíll nacionalisme català, que may ha estat separatista, que sempre ha sentit intensament l'unió germanívola de les nacionalitats ibèriques dintre de l'organisació federativa, és aspiració enlairada d'un poble que, ab consciencia del seu dret y de la seva força, marxa, ab pas segur, pel camí dels grans ideals progressius de la humanitat» (Prat de la Riba, 2007: 114-115).

B CLIVATGE, número 7

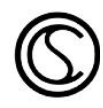


Ovejero (2011), de hecho los diez apellidos más frecuentes en Cataluña son claramente de origen no catalán. Por ello, si en el XIX la idea de nación catalana podía estar, digamos, bastante delimitada, conforme se avanzó en el XX se fue produciendo una mezcla de los nativos con los recién llegados $\mathrm{y}$, por ello mismo, también hubo no pocos catalanes que lamentaron el proceso de «invasión silenciosa» de los llamados «charnegos», así como temieron la españolización de la cultura catalana. ${ }^{20}$

\section{Josep Benet y el ideal de «un sol poble»}

La llegada de tantas personas del resto de España explica que el ideal integrador impulsado por Josep Benet (1920-2008), que fue promovido y debatido sobre todo a partir de los años 60, ocupara un lugar central. ${ }^{21}$ Para referirse al conjunto de catalanes difundió la expresión «un sol poble», en su origen de Aureli Maria Escarré (1908-

20 El más famoso de ellos fue quizá Josep Anton Vandellós (1899-1950), autor de obras como Catalunya, poble decadent (1935) y La immigració a Catalunya (1935). También hubo otras figuras importantes que destacaron por sus afirmaciones racistas, desde Pompeu Gener (1848-1920) hasta Pere Màrtir Rossell i Vilar (1882-1933) o Carles Sentís (1911-2011), futuro diputado por UCD durante la Transición. De 1934 es el Manifest per la raça catalana, suscrito entre otros por Pompeu Fabra (1868-1948) y Josep Maria Batista i Roca (18951978). Más tarde, este tipo de reacciones se han reducido en número, pero actitudes semejantes se han detectado en políticos como Heribert Barrera (1917-2011), histórico dirigente de ERC. La polémica designación de Quim Torra como presidente de la Generalitat y la difusión de varias de sus controvertidas afirmaciones han servido para recuperar este debate.

21 Para comprender la figura de Josep Benet, véase sobre todo el libro Com una pàtria, de Jordi Amat. 
1968) y que se desvinculaba totalmente de un Volk de trasfondo herderiano, que hizo gran fortuna y se sigue repitiendo en la actualidad. ${ }^{22}$ En opinión de Benet, se debía cultivar la convicción de Jaume Vicens Vives (1910-1961), manifestada en Notícia de Catalunya, de que ésta era hija del mestizaje. Desde esta perspectiva, los inmigrantes del resto del territorio español no debían ser considerados como extranjeros o invasores. ${ }^{23} \mathrm{Al}$ contrario, debían ser

22 En un discurso pronunciado en Badalona en ocasión del centenario del nacimiento de Pompeu Fabra y que reivindicaba el cultivo y la recuperación de la lengua catalana, proclamó: «Nosaltres malgrat tot el que ha passat -i el que encara passa- no hem abandonat ni la tasca ni l'esperança. Per això continuem treballant en refer aquest país nostre i per restituir al nostre idioma el lloc que li correspon com a llengua del poble i com a instrument de cultura. I en aquest treball - en aquest combat, diria - ens hi trobem tots els ciutadans d'aquest nostre país que volem viure en democràcia i llibertat. Tots, tants els catalans d'origen com els altres catalans. Tots units, com ens trobem en aquesta sala, avui, retent homenatge a Pompeu Fabra. Tots reclamant que l'ensenyament del català sigui una realitat per a tothom, perquè a Catalunya ningú no es pugui sentir discriminat per raó d'idioma. Perquè uns i altres, catalans de llinatge i nous catalans, formem un sol poble» (Benet, 1980: 33). Vicens Vives, en Notícia de Catalunya, ya había apuntado que «som fruit de diversos llevats i, per tant, una bona llesca del país pertany a una biologia i a una cultura del mestissatge» (1999: 20).

${ }^{23}$ Para ello, se esforzó asimismo en mostrar que el racismo no formaba parte de la principal herencia catalanista y puso como precedentes a Francesc Macià («Todos los catalanes, los de sangre, los de lengua, los de nacimiento, los de residencia, participarán en las ventajas de la organización autonómica. Consideramos también catalanes, queremos subrayarlo, a todos aquellos que, residiendo en nuestra tierra, conviven con nosotros y se sienten compenetrados con nuestros anhelos e ideales»), Rafael Campalans («Para nosotros la nación es algo vivo, lleno de sentido y orientado al futuro, y la raza es algo muerto, pobre de contenido y plasmada en el pasado (...). Para nosotros, 
vistos como otro tipo de catalanes con los que se podía luchar conjunta y simultáneamente contra la dictadura de Franco y a favor de las libertades políticas y sociales de Cataluña. ${ }^{24}$ La apelación al poble aparecía así como la forma oportuna de reunir los dos ejes, tanto el nacional como el antifranquista.

Para ello, Benet se apoyó en el artículo y luego en el libro Los otros catalanes, de Paco Candel (1925-2007), ${ }^{25}$ obra que él mismo

los forasteros que vienen a Cataluña - que siempre acogemos con los brazos abiertos - y sufren nuestros duelos y gozan con nuestras alegrías, y nos dan hijos (...) son tan catalanes como nosotros mismos. No hacemos absolutamente ninguna diferencia») e incluso Enric Prat de la Riba, rescatando una carta que el político catalán escribió a Clarín y en la que escribió: «Nacionalidad y raza no son una misma cosa. Y gentes de estirpe castellana pueden ser y llegan a ser tan catalanas de carácter, de aficiones y sentimientos, como los que procedemos de una familia catalana de siglos» (para todo ello, Benet, 1978: 66-67). En esta nómina ya se podría incluir a Pere Coromines, quien en 1914 escribió: «Al costat dels 500.000 barcelonins, que són fills de la terra catalana, n'hi ha a la nostra ciutat 120.000 que han vingut de fora de Catalunya a fecundar el nostre país, a fer-lo progressar. Hi ha qui voldria que això fossin dues ciutats enemigues, eternament separades per l'odi (...). Barcelona és de tots els qui treballen per ella i l'estimen» (citado por Termes, 1984: 140). Por su parte, cabe recordar que, en Errores catalanistas (1896), Sabino Arana ya había escrito que «La política catalana consiste en atraer a sí a los demás españoles; la vizcaína en rechazar de sí a los españoles como extranjeros (...). Los catalanes quisieran que no sólo ellos, sino también todos los demás españoles establecidos en su región hablasen catalán; para nosotros sería la ruina el que los maketos residentes en nuestro territorio hablasen euskara» (Arana, 1965: 401ss).

24 Todavía Joan Rigol escribirá en 1986, en Poble i Consciència nacional, un libro por cierto antecedido por una introducción de Josep Benet, que «un poble que crea marginacions s'autodestrueix com a poble» (1986: 66).

${ }^{25}$ Ya en el año 1962, en su Sobre les inundacions de setembre, Josep Benet se refirió como «otros catalanes» a esa mayoría de víctimas de las inundaciones 
había encargado después de haber leído el artículo homónimo que este último había publicado en 1957. Escrito desde la perspectiva de inmigrante, en Los otros catalanes se proponía una lectura inclusiva de esos catalanes de adopción que será también defendida por Benet. ${ }^{26}$ De este modo, se combatía la interpretación identitaria, excluyente y xenófoba del nacionalismo y se ensanchaban los límites del significante nación. Aunque hubo catalanesque no compartieron sus posiciones, ${ }^{27}$ el libro cosechó un gran éxito editorial y se convirtió en uno de los grandes best-sellers de la década en Cataluña.

que eran inmigrantes pobres. En un sentido semejante, señaló que otro tema de debate que no se podía esquivar más era «com són acollits, a casa nostra, aquests immigrats que per llur treball es converteixen en catalans» (Benet, 1980: 140).

${ }^{26}$ De hecho, en un principio se había pensado que el título del libro podía ser Nosaltres, els immigrants, a imitación del Nosaltres, els valencians de Joan Fuster, cosa que Francesc Candel rechazó. Este mismo título apelaba a Nosaltres, els catalans, el nombre que se pensó originalmente para la conocida obra Notícia de Catalunya, de Jaume Vicens Vives. Más adelante, Alfonso Carlos Comín escribiría Noticia de Andalucía (1970), uno de cuyos capítulos se titulaba, en referencia a Candel, Los otros andaluces.

${ }^{27}$ En seguida, en 1965 se publicó la obra Els no catalans i nosaltres, de Manuel Cruells. En su opinión, los inmigrantes «poden ésser la nostra futura vitalitat econòmica evidentment, però poden ésser també un ferment de descomposició del que els catalans considerem essencial, si ells o els seus fills es queden en l'estadi impossible d'ésser uns simples "catalans" o només uns "altres catalans", cosa que no vol dir res. I, si vol dir alguna cosa, és que no s'és carn ni peix (...), no hi ha uns "altres catalans", només hi ha uns catalans. Tant si han nascut aquí, ara o abans, tant si són acabats d'arribar. No som ni discriminacionistes ni racistes. Admetem tothom en aquesta situació de catalans mentre es comportin com a catalans. I aquest comportament significa evidentment una dedicació, un 
Por todo ello, no debe extrañar que Benet, aun proviniendo de las filas de Unió Democràtica de Catalunya, acabara siendo candidato a la Generalitat por el PSUC en las elecciones catalanas de 1980. En esa misma época, bajo el pseudónimo de Roger Arnau, publicó Marxisme català i qüestió nacional catalana (1974), y, bajo el de Oriol Puigvert, reeditó y prologó la obra de Andreu Nin (1892-1937). Sendos gestos apuntaban contra esas interpretaciones, como la atribuida de manera exagerada a Jordi Solé Tura, que reducían el nacionalismo catalán a no ser más que un simple producto de la burguesía catalana. ${ }^{28}$ Uno de los mayores momentos de gloria de Benet se dio en las elecciones generales de 1977, cuando fue escogido senador por Entesa dels Catalans con el mayor número de votos de toda España. Curiosamente, el segundo fue Paco Candel.

Desde entonces, la política catalanista ha basculado entre las ideas de pueblo y de nación. De ahí que décadas más tarde la

entusiasme, una fidelitat al que és fonamental per a Catalunya» (Cruells, 1965: 12ss).

${ }^{28}$ Se debe señalar que el mismo Solé Tura no tardó en matizar dichas tesis y ya en la misma Introducción que añadió a su traducción al castellano señaló, en unas frases que sintomáticamente pasaron desapercibidas, que «no debe creerse que la historia del nacionalismo catalán es, únicamente, la historia del nacionalismo de la alta burguesía. Ha habido una fase pequeño-burguesa altamente interesante, con un fuerte impulso de masas, y ha habido también varios intentos de ligar la solución del problema catalán con la lucha reivindicativa y política de la clase obrera» (1970: 10). En la actualidad, un historiador tan crítico con el independentismo como Jordi Canal ha escrito en Con permiso de Kafka que «la polémica algo artificial entre Jordi Solé Tura y Josep Termes sobre los orígenes burgueses o populares del catalanismo y el nacionalismo es ya de otra época y poco aporta» (2018: 59).

B CLIVATGE, número 7

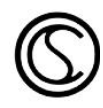


politóloga Montserrat Guibernau haya hablado de un nacionalismo cosmopolita o que Xavier Rubert de Ventós lo haya hecho de un nacionalismo postidentitario, mestizo e incluso bilingüe. En un mismo sentido, se ha defendido la existencia de un nacionalismo democrático, liberal, cívico, social y/o incluso postnacional, los cuales intentarían superar el de carácter étnico. Ahora bien, más que hablar de uno solo de ellos habría que ver cómo se combinan e interaccionan todos estos rasgos en la práctica y no de una manera no problemática ni siempre consistente. En este sentido, es fundamental tener en cuenta que, siguiendo lo apuntado por Rogers Brubaker (1996), el nacionalismo debe ser entendido como una categoría en buena medida práctica y dinámica que, por ello, tiene la capacidad de regenerarse, acomodarse y redefinirse según las diferentes coyunturas. Del mismo modo, también las fronteras o los rasgos del concepto de nación pueden ser modificados y reapropiados por sus agentes. En un caso como el catalán, tan marcado por la inmigración, fuera por virtud o por necesidad, su supervivencia solo podía pasar por integrar la pluralidad en su seno y eso condujo de paso a diluir, o cuando menos matizar, sus componentes más identitarios y propiamente nacionalistas. ${ }^{29}$ En verdad, ya no solo se trata de que la

${ }^{29}$ Así lo consideró el mismo Josep Termes: «Amb la immigració, Catalunya va triar un camí sense retorn. No hi ha altra sortida que la lluita per la integració d'aquesta (...). Cal, doncs, obligadament, treballar per la integració dels immigrats, que, per altra part, tant han contribuït al creixement de Catalunya, $\mathrm{i}$ que molts d'ells -i dels seus fills- estimen més que alguns catalans, i amb més sofriment i abnegació. Aquesta és la via, i no cap altra. O es produeix la integració, o Catalunya es desnacionalitza en una generació» (1984: 188).

B CLIVATGE, número 7

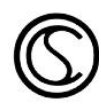


misma nación sea mestiza, sino de que, como se evidencia con la apelación a «un sol poble», lo es el mismo concepto en sí.

El mismo Jordi Pujol, representante por antonomasia del nacionalismo catalán en el último cuarto del siglo XX, adoptó desde un principio la postura impulsada por Josep Benet — «cal anar a aquesta integració, que tots siguem uns, un sol poble» (Pujol, 1976: 68-69)—, celebró en público la obra de Paco Candel - lo retrató como «l'home que potser més ha fet, o dels que més, per tal que el problema de la immigració s'encarrilés per camins positius» (Pujol, 1976: 20)-y definió al catalán como aquel que vive y trabaja en Cataluña (y para Cataluña podríamos añadir), ${ }^{30}$ sin que (al menos a nivel teórico) importara su lugar de procedencia. Años después, en mayo de 1984, defenderá ese mismo ideal y dirá que «el mayor bien de un pueblo es su convivencia y Cataluña es un solo pueblo» (citado por Espasa, 2009: 34). ${ }^{31}$ En 1988 insistirá todavía en que «tots els qui vivim i treballem a Catalunya hem de ser un sol poble, un sol poble català» (Pujol, 1988: 17). Ahora bien, desde un buen principio también dejó claro que el auténtico problema político de Cataluña, el único verdadero, aclaró, era la inmigración. «És aquí on ens juguem l'ésser

\footnotetext{
30 Una de sus primeras formulaciones es la siguiente: «Català és tot home que viu i treballa a Catalunya, i que amb el seu treball, amb el seu esforç ajuda a fer Catalunya. Hem d'afegir-hi només: i que, de Catalunya, en fan casa seva, és a dir, que d'una manera o altra s'hi incorpora, s'hi reconeix, s'hi entrega, no li és hostil» (Pujol, 1976: 69-70).

31 En 1980, en la reedición de Construir Catalunya, se habían suprimido sin avisar tres textos, en uno de los cuales (titulado L'exèrcit d'ocupació y publicado en 1965) se refería a los inmigrantes como «ejército de ocupación».
} 
o el no ésser del nostre poble», añadió. ${ }^{32}$ Por ello, sus detractores han visto su proyecto y el de sus sucesores como uno que en verdad era de carácter asimilacionista, pese a que el político prefirió evitar la palabra «asimilación» y apostó por la de «integración». En lo sucesivo, el debate girará implícita o explícitamente en torno a estas dos palabras. Ahora bien, en muchos casos sería más preciso hablar de «incorporación», pues el objetivo, con mayor o menor fortuna, ha sido más incorporar a los inmigrantes al proyecto político catalán y/o catalanista. ${ }^{33}$

Desde un prisma anacrónico, puede leerse el gesto de Benet, un ideal que hasta nuestros días ha jugado un rol central, como una salida populista (y quién sabe si pragmática y/o voluntarista) frente a los límites tradicionales del nacionalismo: el pueblo, un pueblo por definición plural y heterogéneo, apareció así como la mejor solución al problema de la nación. En sintonía con las teorías del populismo,

32 En otro texto dirá: «La immigració és el problema més important que com a poble tenim plantejat. Tots els altres problemes els resoldrem més tard o més d'hora, més bé o més malament. Fins i tot alguns d'ells ens vindran resolts des de fora. Però aquest, no: aquest és un problema específicament nostre, que només podem resoldre nosaltres, i que si no el resolem bé, a través d'una fosa harmònica i positiva de tots els habitants de Catalunya, produirà la nostra definitiva dislocació com a poble» (Pujol, 1976b: 149-150).

33 El mismo Manuel Cruells escribió, en Els no catalans i nosaltres, que «els catalans tenim l'obligació d'acollir aquest emigrant, que és arrel de poble, i plantar-lo entre nosaltres perquè creixi, amb alegria $i$ amb esperança», pero advirtiendo poco después que «no seran catalans fins que parlaran com nosaltres, fins que es faran seves les nostres necessitats (...), fins que se sentiran ferits quan veuran menystingudes les coses de Catalunya» (1965: 31). 
esta idea de pueblo también cimentó su unidad sobre un antagonismo, uno en el que, gracias al contexto de la época, se podían asociar fácilmente la causa catalanista y la antifranquista. Al mismo tiempo, con ello se apuntaba a bloquear e incluso revertir las estrategias de la dictadura de debilitar y fragmentar el catalanismo político. Estas maniobras derivaron en fallidos proyectos regionalistas divisorios como el leridanismo o el menos conocido tortosismo.

La causa común contra Franco facilitó la lucha conjunta de «viejos»y «nuevos» catalanes. Más adelante, durante la transición, muchos inmigrantes apoyaron un buen número de causas catalanas y defendieron la aprobación de un estatuto de autonomía para Cataluña. Ejemplos famosos de este acercamiento fueron la primera Diada de la transición, que tuvo lugar en 1976 en un lugar habitado sobre todo por inmigrantes como Sant de Boi de Llobregat; también la primera escolarización pública en catalán, impulsada en Santa Coloma de Gramanet y su escuela Rosselló-Pòrcel, o la ley de inmersión lingüística de 1983, aprobada con el voto de todos los partidos políticos en Cataluña, incluyendo el Partido Socialista Andaluz (que entonces tenía representación en el Parlamento catalán) y Alianza Popular. ${ }^{34}$ Dos décadas más tarde, todavía el Estatut de 2006 será

${ }^{34}$ Cabe recordar, además, que el modelo que se adoptó no era el originalmente planteado por CIU, sino el promovido por el PSUC y apoyado por el PSOE. Como ha escrito la historiadora Paola Lo Cascio, «malgrat que CiU es presentà a la discussió amb un text propi -que recollia (...) l'elecció en favor d'una doble xarxa escolar i l'establiment de sancions per als infractors de la llei-, al llarg del debat el govern va acabar per abandonar del tot els seus postulats inicials davant l'evidència que aquests eren insuficients per a la creació d'un consens

B CLIVATGE, número 7

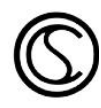


votado favorablemente por todos los partidos políticos a excepcióndel Partido Popular. Durante mucho tiempo, la idea e ideal de «un sol poble» pareció muy robusta.

Al mismo tiempo, sin embargo, sostengo que esa idea de doble lealtad ha perdurado de algún modo en al menos parte del escenario catalán. La causa independentista ha sido bastante minoritaria hasta la primera década del siglo XXI y, para mucha gente (en especial la que votaba a Felipe González en las generales y a Jordi Pujol en las autonómicas), no era incompatible sentir una suerte de fidelidad simultánea hacia Cataluña y hacia España. El problema surgió más adelante, cuando la conflictividad aumentó y un buen número de gente acabó por poner a una por delante de la otra. De una relación con ciertas tensiones con el gobierno de Madrid se fue pasando a una defensa y una apuesta por la ruptura con España.

No se debería hacer una lectura estrictamente identitaria de las respuestas que se dieron en esta situación: a modo de ejemplo, Unió Democrática de Catalunya, partido conservador y nacionalista catalán, se posicionó en contra de la independencia, no sin importantes deserciones por en medio, y concurrió con el PSC en las elecciones autonómicas del 21 de diciembre de 2017. Además, aunque los orígenes de cada persona y el entorno cultural y/o lingüístico en el que se mueve influyen, no son pocas las personas como Josep Borrell,

ampli. Finalment, el model de normalització lingüística inaugurat a partir de la llei de 1983 - i en particular el model lingüístic escolar de xarxa única- deu els seus eixos fonamentals als plantejaments de les forces d'esquerres, i en particular del PSUC» (2008: 343). 
descrito a menudo como un catalán de soca-rel, que están posicionadas claramente en contra del independentismo; ni al revés, quienes como Gabriel Rufián, hijo de andaluces, se han identificado con la causa independentista. Al mismo tiempo, muchos políticos catalanistas previamente adscritos al federalismo se han decantado por una postura proclive o comprometida con la independencia, algo que ha afectado de lleno a la estructura interna del PSC, partido catalanista que prefirió evitar el marchamo de nacionalista: entre sus «fugitivos» destacan actores políticos como los antiguos consellers Ernest Maragall, Montserrat Tura, Joaquim Nadal, Marina Geli o Toni Comín. Sin duda, los orígenes influyen en los posicionamientos políticos, pero no bastan para comprender la complejidad del problema. Y esa complejidad se da en ambos bandos, pues es obvio que no se es menos catalán por estar en contra de la independencia.

\section{Las razones de la independencia}

Todo lo anterior explica que, a nivel discursivo, la mayoría de independentistas justifiquen su posicionamiento debido no tanto a razones de carácter clásicamente nacionalista, sino a lo que juzgan como la imposibilidad de un encaje político con el Estado español, a un deseo de mayor autonomía, al fracaso del federalismo, al deseo de instaurar una república y/o a la voluntad de promover un nuevo y más democrático proceso constituyente, donde se entremezclan la decepción o el hartazgo por la deriva política de los últimos años con la esperanza de un cambio a mejor. En este contexto, también ha tenido un gran eco la formulación de Marina Subirats, quien ha

B CLIVATGE, número 7

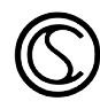


destacado que la independencia ha aparecido para mucha gente como una suerte de «utopía disponible». En una línea parecida cabe entender el eslogan de Súmate, la plataforma hispanoparlante e independentista, que reza: «No importa el origen, sino el destino». La razón de ser de la independencia, así pues, se encontraría más en el futuro que en el pasado. En tales casos, la comunidad a la que se apela no es tanto la pretérita como la deseada para el futuro y la apelación a la independencia adquiere un sentido a menudo instrumental. De hecho, según la encuesta del CEO de otoño de 2017 solo un 9\% de independentistas ha declarado basar su posicionamiento en sentimientos identitarios. Se trata de un dato cuando menos sorprendente, que evidencia la complejidad del conflicto catalán.

Ahora bien, habría que repensar qué significa exactamente este 9\%. Para empezar, no está claro hasta qué punto son fiables razones aducidas para justificar la propia posición independentista como las mencionadas anteriormente y que lo nacionalista juegue un rol tan exiguo. En definitiva, las personas prefieren apelar a las mejores razones para justificar la posición política propia (y el desprestigio del nacionalismo seguramente influye a la hora de no poner la cuestión identitaria como un factor central). No obstante, tampoco se debe descartar del todo este dato, pues no se debe olvidar que en las elecciones generales del 20 de diciembre de 2015 y del 26 de junio de 2016 el partido más votado en Cataluña fue Podemos (una formación que, pese a abogar por la autodeterminación, es detestada por muchos independentistas $\mathrm{y}$ en no pocas ocasiones es presentada exageradamente como una forma de neolerrouxismo) y que en sendas

B CLIVATGE, número 7

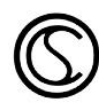


ocasiones la suma de partidos independentistas se quedó entorno al $30 \%$, algo que contrasta con las mayorías absolutas alcanzadas por los independentistas en el gobierno autonómico justo antes y después de esas elecciones generales, tanto en las de 2015 como las de 2017. Es decir, un buen número de personas han votado en clave independentista para Cataluña y en no independentista para la formación de un gobierno en España. ¿Es eso una contradicción? ¿Y cómo cuadraría este dato con la imagen clásica que se ha querido ofrecer de los nacionalistas?

Por ello, se debería tener en cuenta que una de las causas de crecimiento de partidarios de la independencia se debe a una suerte de desreconocimiento o, en esta misma línea, a lo que podemos llamar desrepresentación; es decir, por el hecho de que muchos catalanes no se sienten justamente representados e incluso perjudicados por el gobierno de Madrid. Se trata de un problema complejo que no solamente se circunscribe a las últimas décadas. ${ }^{35}$ La cuestión es que esta sensación de desrepresentación ha fomentado la percepción de sentirse incomprendidos y perjudicados por un buen número decisiones gubernamentales. ${ }^{36} \mathrm{El}$ ejemplo por excelencia de este

\footnotetext{
${ }^{35}$ Pensemos en que, sea casualidad o no, sea anecdótico o no, no ha habido presidentes del gobierno catalanes en España desde el lejano 1873, justamente con un federalista como Francesc Pi y Margall. Por su parte, Borja de Riquer (2016: 42) ha calculado que, de los aproximadamente 850 ministros españoles que hubo entre 1814 y 1900, solo 22 eran catalanes, casi la mitad de ellos, por cierto, durante el Sexenio Revolucionario.

${ }^{36}$ Véase como ejemplo de estas críticas el libro de Germà Bel, Espanya, capital París: tots els camins porten a Madrid.
}

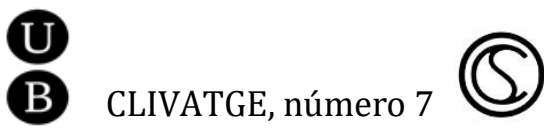


problema habría estado protagonizado por las decisiones y discursos del Partido Popular, una formación abiertamente contraria al catalanismo y promotor de campañas espectaculares como la que hicieron en contra del Estatut, considerada hace no mucho excesiva incluso por una persona de primera línea del propio partido como la antigua vicepresidenta Soraya Sáenz de Santamaría. Dicho partido, que ha sido el hegemónico en los últimos lustros en España, no ha sido en cambio nunca una formación de primera línea ni ha sido nunca una posible candidata al gobierno en Cataluña. Sin ir más lejos, en ninguna de las elecciones a la Generalitat, por ejemplo, ha logrado superar la discreta cifra de un $13 \%$ de votos y solo en los comicios generales de 2000 , justo después de que Jordi Pujol hubiera pactado con ellos tanto en Madrid como en Barcelona, logró traspasar el umbral del 20\%.

Esta sensación de desrepresentación ha ayudado a la confección de un relato en el que el recuento de los agravios padecidos ha ocupado un rol esencial en Cataluña. En verdad, no se trata de una reacción nueva. No por casualidad, ya la quinta sección de un documento ejemplar de esta tendencia como el Compendi de la doctrina catalanista (1894), redactado por Enric Prat de la Riba i Pere Muntanyola, se tituló «Agravis» (sic), y en él podemos leer frases como «Gayre be tots los fets de la nostra historia posteriors á la vinguda de la dinastía castellana, enclouen algun agravi». Como observó Leah Greenfeld al analizar nacionalismos como el ruso y el alemán, el resentimiento, justificado o no, ha tendido a desempeñar un rol importante en este tipo de movimientos políticos. Por eso no debe extrañar que Francesc Ferrer i Gironés (2000) en un libro que sigue

B CLIVATGE, número 7

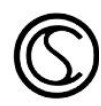


esta línea como es Catalanofòbia, comience cobijándose en la tesis de Isaiah Berlin y vincule el origen del nacionalismo al hecho de sentirse tratados injustamente o menospreciados. ${ }^{37}$ En un sentido semejante, el filósofo Charles Taylor también apuntó que «una de las facetas del nacionalismo es que constituye una respuesta a una amenaza a la dignidad» (Taylor, 2014: 76).

A nivel fáctico, y en consonancia con no pocos de los otros fenómenos políticos contemporáneos, la legitimación pública del nacionalismo catalán se ha entendido en mayor medida en clave indirecta que directa, más desde la deslegitimación del otro que de la legitimidad del propio proyecto. ${ }^{38}$ Como ha escrito el historiador Xosé

37 El pensador británico también señaló que «el nacionalismo es un estado de inflamación de la conciencia nacional que puede ser tolerante y pacífico, y lo ha sido a veces. Parece que su causa suelen ser heridas, alguna forma de humillación colectiva» (Berlin, 2002: 393-394).

38 No se trata de algo novedoso. Pensemos, por ejemplo, en el rol de la crisis de 1898 o, tal y como ha analizado Borja de Riquer (2001), en la ruptura del canovismo con el conservadurismo catalán para el ascenso del nacionalismo catalán. En 1899, Manuel Duran i Bas ya escribía a Silvela que «va acentuándose aquí la creencia de que dentro de breves años sufrirá España una desmembración; este peligro comienza a mirarse como natural y, lo que es más triste, con indiferencia. Se reconoce que Cataluña podrá ser absorbida por Francia, pero lo más alarmante del hecho es que la contestación que se da a los que hacen tal advertencia es la siguiente: peor gobernados que por la gente de Madrid no lo podemos estar» (citado por Riquer, 2001: 185). Antes, en 1881, ya le había escrito en un tono semejante: «Va penetrando en todas las clases sociales la doble idea de que en Madrid se desdeña en general todo lo que no son intereses exclusivos de la Corte y que sobre todo se tiene mala voluntad a Cataluña. Y esta doble idea va uniendo a todas las clases sociales. Y hasta aproximando a todos los partidos». De ahí que, años más tarde, Ortega 
Manuel Nuñez Seixas, «existe una relación constante entre el desarrollo del nacionalismo español y el nacimiento y la evolución de los "nacionalismos periféricos": los éxitos del primero condicionan el fracaso de los segundos, y viceversa» (Núñez Seixas, 2010). Desde luego, eso no quiere decir que el proyecto independentista se funde únicamente en el descrédito o en la pérdida de confianza hacia España, entre otras cosas porque no convendría confundir las razones (sean públicas o privadas) con las mismas causas reales de lo sucedido, pero sí que la imagen negativa de España ha influido y por ello ha sido continua y oportunamente cultivada desde los media nacionalistas e independentistas de Cataluñacon el fin de reforzar su posición política.

Como ejemplo de esta actitud cabe recordar el mantra de que el Partido Popular o el nacionalismo español son «fábricas de independentistas». ${ }^{39} \mathrm{Y}$ algo semejante había sucedido ya antes, cuando Benet captó que uno de los elementos cohesionadores del ideal de «un sol poble» era la común oposición a Franco. Después de la caída de su dictadura, continuaron denunciándose los nuevos

escribiera que el mejor modo de vencer a los nacionalismos separatistas consistiese en ofrecer un proyecto mejor de España: «Un Estado en decadencia fomenta los nacionalismos: un Estado en buena ventura los desnutre y los reabsorbe» (Ortega, 2004: 71).

${ }^{39}$ En un sentido semejante, se debe entender la conocida frase de Xavier Rubert de Ventós: «els catalans no serem independents fins que no ens hi obliguin». Más recientemente, Joaquim Nadal, antiguo candidato del PSC a la Generalitat, ha escrito que «l'obstinació anticatalana transversal de l'espanyolisme m'abocava cap a l'independentisme» (Nadal, 2018: 14).

B CLIVATGE, número 7

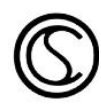


agravios, desde la fallida LOAPA hasta la campaña contra el Estatut y recientemente las cargas policiales del 1 de octubre o la aplicación del artículo 155 de la Constitución. Por ello, no han sido pocos los intentos de defender que el franquismo sigue plenamente presente en las instituciones españolas o que Cataluña vive en una suerte de situación colonial. Otra cosa es que estos argumentos hayan concitado una adhesión equivalente a la lograda durante la primera parte de la transición en Cataluña o fuera de ella.

Desde esta perspectiva, y por cierto a semejanza del nacionalismo de Estado, el de carácter separatista se presentaa menudo como un nacionalismo reactivo y defensivo, uno que existe como un acto de supervivencia o de resistencia frente un nacionalismo agresivo de Estado que ahoga su cultura y les impide desarrollarse de una manera natural.Esto es, una especie de nacionalismo tímido que tiene miedo a admitirse como nacionalista y que lo hace básicamente en situaciones en que considera que la supervivencia de la propia cultura está en peligro. ${ }^{40}$ Una posición semejante la hallamos por ejemplo en Joan Fuster (1922-1992), quien en su conocido artículo Contra el nacionalisme ya escribió con vehemencia que «o ells [los españoles] renuncien al seu nacionalisme,

40 Por supuesto, y siguiendo una lectura del nacionalismo como la procurada por Leah Greenfeld y que vincula nacionalismo y democracia, no han faltado las excepciones. Por ejemplo, Joan B. Culla ha defendido que «el nacionalisme s'ha de desacomplexar, ha de treure's del damunt el complex d'inferioritat, de dretanisme, de "barretina", que hom intenta infondre-li des de fa anys, ha de recobrar la plena autoconsideració com a valor de progrés que ha estat quasi sempre al llarg de la seva història» (Culla, 1987: 41).

B CLIVATGE, número 7

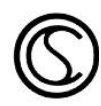


o els altres haurem de ser nacionalistes» (1976). A grandes rasgos, se trata de una actitud que ya hallamos en un lejano 1855, en una fecha en que aún se hablaba en términos de provincialismo. Entonces, Illas i Vidal (1819-1876) había advertido en Cuestiones catalanas que:

no se dirá que Cataluña tiende a una separación del Reino de Castilla, especie a la que se ha dado ahora últimamente alguna importancia (...). Esto que parece a algunos deseos de la emancipación (...) no es sino el grito de la indignación contra la injusticia. Si un día fuera otra cosa, no provendrá ciertamente de lo que ahora existe, sino de lo que vendrá después: provendrá de que rebosará la copa del sufrimiento (citado por Riquer, 2001: 140).

\section{El nacionalismo en su laberinto}

Por todo lo anterior, no han faltado las corrientes que, aun proclives a una separación o cuando menos una mayor autonomía respecto al territorio español, han sido críticas con los postulados identitarios y a veces xenófobos o supremacistas del nacionalismo catalán. De ahí, por ejemplo, la manida distinción entre ser catalanista y nacionalista, donde lo primero (usualmente encarnado por el Partido Socialista de Cataluña o Iniciativa per Cataluña y justificado por textos como los de Ernest Lluch) no sería más que una versión light y cívica de lo segundo.

Lejos de ser una distinción reciente, esto resume las constantes preocupaciones históricas que ha habido en Cataluña por desmarcarse de una versión conservadora y etnicista del 
nacionalismo. Por ejemplo, cabe recordar que, ya a fines del XIX, Josep Narcís Roca i Farreras (1834-1891) criticó las formas de catalanismo «regresivo»y abogó por uno «progresivo» que, frente a un patriotismo agresivo, enarbolaba uno defensivo. Más adelante, Rafael Campalans (1887-1933), en su texto Nacionalisme i nacionalisme, publicado seis semanas antes del golpe de estado de Primo de Rivera, reivindicó un tipo de nacionalismo que no debe ser entendido como xenófobo sino reformista y contrario a la opresión. ${ }^{41}$ En su polémica con Antonio Fabra Ribas (1879-1958), Andreu Nin, inicialmente en la CNT y luego fundador del POUM, afirmó en Socialismo y nacionalismo estar en contra de los nacionalistas pero a favor del nacionalismo. Casi dos décadas después, en su obra central, Los movimientos de emancipación nacional, defendió el principio de autodeterminación, que recoge la famosa posición adoptada por la II Internacional en el Congreso de Bruselas de 1896, y señaló que la lucha obrera debía ir

41 Dicho texto comenzaba con las conocidas líneas «ha estat costum a casa nostra, confondre en una mateixa paraula, nacionalisme, l'expressió de dues idees ben diferents. D'una banda, la clàssica doctrina política nacionalista essencialment tradicionalista, imperialista i xenòfoba-, i d'altra banda el moviment reivindicador dels drets de les nacionalitats sotmeses. Com és ben clar, res no tenen a veure les dues nocions que, pels homes d'esperit liberal, són, a més oposades i antagòniques» (citado por Lladonosa, 2013: 81-82). Consciente de que dicha explicación podía no ser compartida o comprendida, narró luego cómo el mismo Albert Einstein, en su visita a Barcelona, se mostró inicialmente perplejo ante lo que le contaba y finalmente lo apoyó al no verlo como un nacionalismo verdadero. De todos modos, el físico alemán lo habría descrito como un socialismo nacionalista paradójico y le recomendó desprenderse de la funesta palabra «nacionalismo».

B CLIVATGE, número 7

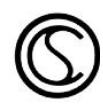


acompañada de la lucha nacional. Joan Comorera (1894-1958), en cambio, histórico dirigente del PSUC, aun estando a favor del derecho a la autodeterminación, se declaró internacionalista y contrario a toda secesión.

Por su parte, aunque ha habido corrientes catalanistas en el anarquismo y se defendieron posturas como la autodeterminación en su seno, seguramente la posición predominante fue no nacionalista. Referentes como Anselmo Lorenzo (1841-1914) y Federica Montseny (1905-1994) consideraron la deriva nacionalista como una causa burguesa que desviaba y enmascaraba la verdadera lucha: la obrera. ${ }^{42}$ En cambio, Jaume Brossa (1875?-1929) sí que defendió una postura abiertamente independentista, que en muchos casos se identificaba con lo que entonces se entendía por autonomía. ${ }^{43}$ Una década antes,

${ }^{42}$ Conocidas son las siguientes líneas que escribió Anselmo Lorenzo en El proletariado militante: «Hay no pocos jóvenes que valdrían mucho si no hubieran nacido en Cataluña, porque refrenando su inteligencia, habrían llegado a las cumbres del ideal, sin empequeñecerla con el idioma catalán, la frontera catalana y el odio a Castilla. Muchos de esos jóvenes son anarquistas, superhombres, necios que no sirven para nada; el catalanismo les inutiliza para la vida intelectual» (1974: 350).

${ }^{43}$ En el artículo Catalanismo y nacionalismo (1899), publicado en La Revista Blanca, escribió: «La cuestión catalana en sus relaciones con la lucha por la libertad y la reforma social que nosotros deseamos presenta un aspecto candente de un valor sustantivo e inmediato. Esta es la actitud que los obreros catalanes deben adoptar ante el problema del autonomismo de Cataluña. Tengo la completa seguridad de que la mayoría de los obreros catalanes que piensan, sienten simpatía hacia todo movimiento que tienda a exaltar el principio autonomista, pues conseguida la independencia de Cataluña, la lucha de clases ha de ser después más fácil y con ventaja para el proletariado (...). Al objeto de 
en 1887, Eudald Canibell (1858-1928) había remarcado en la revista Acracia que "acracia y patriotismo pueden coexistir, al igual que patriotismo y cosmopolitismo» (Canibell, 1887: 243). ${ }^{44}$

Desde el POUM, Joaquín Maurín (1896-1973) sostendrá más tarde y en su libro Hacia la segunda revolución que «la clase trabajadora debe tomar la dirección del movimiento de liberación nacional» (1935: 184). ${ }^{45}$ En su opinión, la revolución solo era posible uniendo la causa obrera con la causa nacional y su objetivo será «desaburguesar» el movimiento catalanista, en su momento en manos no tanto de la burguesía de la Lliga Regionalista como de los «pequeños burgueses» de ERC. En 1931, Jordi Arquer (1907-1981), entonces en las filas del BOC, escribía: «El lema de las masas trabajadoras debe ser: la revolución social concederá la verdadera libertad a los pueblos oprimidos» (citado por Oltra, Mercadé y Hernández, 1981: 158). Joan Vila, por su parte, criticó el falso

impulsar la revolución económico-social, los obreros deben ayudar las reivindicaciones autonomistas, pero sin confundirse con los catalanistas, para poner atención en un ideal más elevado y por encima de exclusivismos de nacionalidad y de clase» (Brossa, 1899).

44 Acto seguido, el texto puntualizaba que «no nos referimos al patriotismo histórico o burgués, de una localidad, comarca o nación a considerar como enemiga a su vecino, hallando malo todo lo de éste y Bueno lo suyo, y viviendo siempre dispuesto a querellarse contra aquellos que sean considerados extranjeros. Esto, que podría ser considerado por algunos como expresión de amor patrio, es para nosotros puro salvajismo y nada más».

45 En uno de sus discursos había dicho: «Somos separatistas. Pero no separatistas de España, sino del Estado español. En España hay una pugna entre el estado y las nacionalidades oprimidas. Hay que desarticular el estado, romperlo, quebrantarlo» (citado por Bilbeny, 1988: 200s). 
internacionalismo de las izquierdas españolas y afirmó que «no s'adonen que en nom d'un internacionalisme orb, faciliten o avalen d'una forma indirecta l'opressió de nacionalitats per Estats autoritaris i absorbents» (citado por Termes, 2007: 273).

En la actualidad, bajo otros nombres y etiquetas se han repetido esos debates sobre la posibilidad o no, o la incongruencia o no, de un nacionalismo que a la vez sea de izquierdas. Y también ha habido mucha gente que, pese a considerarse abiertamente independentista, se ha querido presentar como no nacionalista o postnacionalista. Para ello, convendría dirimir antes qué se entiende entonces por nacionalista, pues según el caso el significado y sobre todo la connotación o valoración de esta palabra varía enormemente. También, porque muchas de las razones esgrimidas para justificar la independencia (desde las que denuncian el desajuste fiscal hasta las que ven la independencia como una oportunidad para mejorar la democracia actual) se suelen sostener o acompañar, cuando menos de forma indirecta, de una falta previa de afección o adhesión a la comunidad española. Además, también hay que tener en cuenta que la misma demonización del nacionalismo ha conducido a la pérdida de atractivo de esa etiqueta, en especial en el nivel discursivo, sin admitir o reconocer que hay formas de nacionalismo banal y otras no tan banales que persisten en la actualidad. 0 , en otros casos, que hay mucha más tolerancia con las manifestaciones nacionalistas del propio bando que con las del antagonista.

Lo interesante reside en que, pese a la importancia concedida al rol jugado por la inmigración, no se haya renunciado al término

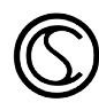


«nación». En los casos mencionados de Montserrat Guibernau o Xavier Rubert de Ventós, se la ha entendido como una nación plural que, de todos modos, sigue siendo una nación que, además, se pronuncia en singular y no en plural, corriendo el riesgo de desplazar la pluralidad a una posición de secundariedad. ¿Acaso tendría sentido hablar de plurinacionalidad también en el caso de Cataluña? No se debe subestimar por ello el rol que la palabra «nación» sigue ejerciendo en este conflicto. Baste tener en cuenta cómo la presencia de este vocablo generó uno de los principales debates que rodearon al Estatut de 2006 y cómo la manifestación del 10 de junio de 2010, la primera soberanista y que respondió a la sentencia del Tribunal Constitucional, se hizo bajo la nada ambigua divisa «Som una nació. Nosaltres decidim». ${ }^{46}$

De nuevo, se intentaba ir más allá de la palabra nacionalidad, aquella que consta para Cataluña en la Constitución española de 1978. Pese a que padres de la Carta Magna española como Gregorio Peces Barba, Manuel Fraga o Miquel Roca aseveraron que «nacionalidad»y «nación» querían decir exactamente lo mismo, la primera se reveló como un término insuficiente políticamente hablando, carente del reconocimiento o las consecuencias políticas deseadas. Al fin y al cabo, la autodeterminación se suele supeditar a la nación y, como se muestra de nuevo en el caso de un politólogo como Joan Vergés, esta

\footnotetext{
46 En un escrito como Als joves de Catalunya, Jordi Pujol ya había dicho, por ejemplo: «En això hem de rebutjar tota mena de compromisos. N'hem d'acceptar molts d'altres, de compromisos, però no aquest. Catalunya és una nació» (Pujol, 1988: 11).
} 
sigue siendo la principal razón aducida para justificar la posibilidad de la independencia. ${ }^{47}$

Ahí es donde reaparece la relevancia del término «pueblo» con el que a menudo, y no pocas veces de manera oportunista, se entremezcla el de «nación». En tales casos, la palabra «pueblo»se manifiesta como una concepción alternativa a la «nación» que en el fondo no deja de estar ligada a esta; como una solución inclusiva que intenta superar o esconder los problemas de la identidad (nacional), pero que igualmente no logra escapar del problema de la identificación o de la delimitación de la comunidad. Es decir, lo que se

${ }^{47}$ En La nació necessària, propone como mejor argumento para justificar la independencia de Cataluña uno en el que la palabra nación ocupa un lugar central (y uno en el que se manifiesta de nuevo el problema del desreconocimiento): «Catalunya té dret a la independència perquè els fets recents i la història demostren que l'Estat espanyol no reconeix Catalunya com a nació ni té la intenció de fer-ho. Aquest no-reconeixement constitueix una injustícia, perquè els catalans han demostrat reiteradament que Catalunya és una nació $i$, malgrat la repressió que han sofert, han lluitat pacíficament perquè sigui reconeguda com a tal. La injustícia s'infligeix a la nació catalana, que no és sinó la comunitat de persones que viuen a Catalunya i que vinculen fortament la seva identitat personal al fet de ser catalans. En tant que nació, encara més en tant que nació maltractada i menystinguda, Catalunya té dret a crear un estat propi si una majoria de catalans així ho desitgen —-mitjançant un referèndum $o$ a través de les decisions que prenguin els seus representants legítims al Parlament de Catalunya. Aquesta voluntat ha de ser presa seriosament en virtut, primer, de la importància fonamental que té per als catalans la pertinença a la nació catalana a fi de poder desenvolupar-se com a persones autònomes i, segon, en virtut de la promoció de l'ideal democràtic - atès que una Catalunya independent funcionarà millor com a democràcia i una Espanya sense Catalunya també complirà millor amb l'ideal democràtic» (Vergés, 2014: 142-143). 
intenta es resolver el problema del cómo, pero no lo hace con el del quién. Y este sigue constituyendo un problema político porque al menos alrededor de la mitad de la sociedad catalana no se entiende dentro de una comunidad donde ser catalán no signifique lo mismo que ser una forma de ser español. En tales casos, se corre el riesgo de caer en una forma de inclusión (en la comunidad correspondiente) desde la exclusión (de su sentimiento de pertenencia o la voluntad de querer ser considerado como miembro de dicha comunidad); es decir, una inclusión forzada que deniega a los incluidos la posibilidad de cuestionar, definir o condicionar su inclusión. A fin de cuentas, por muy inclusiva que se quiera hacer una nación o un pueblo, estos no dejan de tener sus límites y de generar sus propios excluidos. Y esto es algo que, haya independencia o no, no se debería olvidar.

Para acabar, solamente indicar que esto conecta con una doble paradoja actual. Primero, que es en el momento en que Cataluña es más mestiza y heterogénea, menos catalana y más impura según los cánones clásicos del nacionalismo, cuando la independencia se ha llegado a convertir en un problema real de primer orden y, para muchos, en una posibilidad bien real y cercana. ${ }^{48} \mathrm{Si}$ en el pasado el

48 En los años 30, el antes mencionado Vandellós ya había señalado que «suposant que tots els immigrants arribessin a catalanitzar-se, podria donar-se el cas que Catalunya defensés les seves aspiracions amb més força que ara i potser amb més èxit; però, indubtablement, aquelles aspiracions no serien les mateixes que sentim nosaltres. Podria donar-se el cas d'aquí a algunes generacions que Catalunya fos poblada per una gent més patriota que ara, que s'anomenessin catalans, però que no ho fossin sinó de nom perquè els descendents dels forasters haurien assolit la majoria i pres el comandament.

B CLIVATGE, número 7

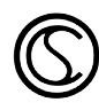


nacionalismo catalán se había entendido mayoritariamente desde el prisma de un doble patriotismo o dentro de una fidelidad a España como Estado o federación de repúblicas ibéricas, ${ }^{49}$ es justamente en el momento en que se intenta superar el esquema clásico del nacionalismo cuando se ha llevado hasta su extremo el desafío político al Estado español. En realidad, de hecho, quizá no sea una casualidad.

Ahora bien, a esta paradoja la acompaña otra no menos importante: eso no ha evitado sino propiciado una división social que, aunque en su gran mayoría sigue siendo no violenta hasta el momento, es más aguda que nunca antes. La idea benetiana de «un sol poble», por ello, resuena en la actualidad como un mito o un ideal quizá utópico e imposible, al menos a corto plazo, en un escenario en que los horizontes no solo de consenso sino de diálogo entre las instituciones correspondientes parecen sumamente difíciles.

\section{Bibliografía:}

Aisa, F. (2006). La cultura anarquista a Catalunya. Barcelona: Edicions de 1984.

Amat, J. (2015). El llarg procés: cultura i política a la Catalunya contemporània (1937-2014). Barcelona: Tusquets.

Aquella Catalunya no fóra de cap manera la continuadora de la nostra història» (1935: 184-185).

49 En su último libro, Breve historia del separatismo catalán, Enric Ucelay ha vuelto a confirmar este punto: «la historia política del nacionalismo catalán resulta autonomista y no secesionista. Fue así desde su intervención en los comicios legislativos (en 1901, con la Lliga Regionalista) hasta la sucesión de Jordi Pujol y la rivalidad de Artur Mas y Pasqual Maragall en la primera década del siglo XXI» (Ucelay, 2018: 9).
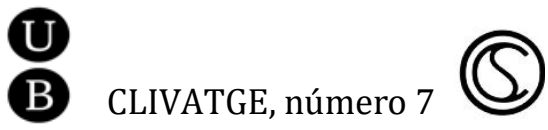
Amat, J.(2017). Com una pàtria: vida de Josep Benet. Barcelona: Edicions 62.

Amat, J. (2018). La conjura de los irresponsables. Barcelona: Anagrama.

Andreu, M. (2015). Barris, veïns i democràcia: el moviment ciutadà i la reconstrucció de Barcelona (1968-1986). Barcelona: L'Avenç.

Andreu, M. (2017). «Un sol poble?», El crític, 15 de octubre de 2017.

Arana, S. (1965). Obras Completas. Bayona: Sabindiar-Batza.

Aznar, J. M. (2007). Cartas a un joven español. Barcelona: Planeta.

Balfour, S. y Quiroga, A. (2007). España reinventada: nación e identidad desde la transición. Barcelona: Península.

Balibar, E. y Wallerstein, I. (1991). Raza, nación y clase: las identidades ambiguas. Madrid: Iepala.

Bartomeus, 0. (2018). El terratrèmol silenciós: relleu generacional $i$ transformació del comportament electoral a Catalunya. Vic: Eumo.

Béjar, H. (2008). La dejación de España: nacionalismo, desencanto y pertenencia. Buenos Aires: Katz.

Bel, G. (2011). Espanya, capital París: tots els camins porten a Madrid. Barcelona: La Campana.

Benet, J. (1978). Desfeta i redreçament de Catalunya i altres parlaments $i$ escrits. Barcelona: Crítica.

Benet, J. (1980). Combat per una Catalunya autónoma: textos d'ahir i d'avui. Barcelona: Bruguera.

Berlin, I. (1997). Nacionalisme. Valencia: Tándem.

Berlin, I. (2002). El fuste torcido de la humanidad: capítulos de historia de las ideas. Barcelona: Península.

Bilbeny, N. (1988). La ideologia nacionalista a Catalunya. Barcelona: Laia.

Brossa, J. (1899). «Catalanismo y nacionalismo». La Revista Blanca.

Brubaker, R. (1996). Nationalism reframed: Nationhood and the National Question in the New Europe. Cambridge: Cambridge UniversityPress.

Cagiao, J. (2018). Micronacionalismos: ¿no seremos todos nacionalistas? Madrid: Los Libros de la Catarata.

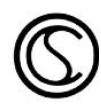


Canal, J. (2018). Con permiso de Kafka: el proceso independentista en Cataluña. Barcelona: Península.

Candel, F. (2002). Els altres catalans. Barcelona: Edicions 62.

Canibell, Eudald (1887), «Preocupaciones y problemas», Revista Acracia, p. 243.

Casassas, J. (2014). La nació dels catalans: el difícil procés històric de la nacionalització de Catalunya. Catarroja: Afers.

Claret, J. y Santirso, M. (2014). La construcción del catalanismo: historia de un afán político. Madrid: Los Libros de la Catarata.

Colomer, J. (1984). Espanyolisme i catalanisme: la idea de nació en el pensament polític català, 1939-1979. Barcelona: L'Avenç.

Colomer, J. (2018). España: la historia de una frustración. Barcelona: Anagrama.

Cortada, J. (1860). Cataluña y los catalanes. San Gervasio:Miguel Blanxart.

Cruells, M. (1965). Els no catalans i nosaltres. Barcelona: Edicions d'aportació catalana.

Culla, J. B. (1987). «Per un nacionalisme desacomplexat». En El nacionalisme català a la fi del segle XX. Vic: Eumo.

Davis, M. (2015). «La teoría perdida de Marx», en New Left Review, 93, pp. 55-78.

Delgado, Luisa Elena (2014). La nación singular: fantasías de la normalidad democrática española, 1996-2011. Tres Cantos: Siglo XXI.

Dowling, A. (2012). La reconstrucció nacional de Catalunya, 1939-2012. Barcelona: Pasado y Presente.

Espasa, A. (et alii) (2009). Fabricar l'immigrant: aprofitaments polítics de la immigració, Catalunya 1977-2007. Lleida: Pagès.

Ferrer i Gironès, F. (2000). Catalanofòbia: el pensament anticatalà a través de la història. Barcelona: Edicions 62.

Fontana, J. (2014). La formació d'una identitat: una historia de Catalunya. Vic: Eumo. 
Forti, Steven; González i Vilalta, Arnau, i Ucelay da Cal, Enric (2017). El proceso separatista en Cataluña: análisis de un pasado reciente (2006-2017). Granada: Comares.

Fradera, Josep Maria (2009). Cultura nacional en una sociedad dividida: Cataluña 1838-1868. Madrid: Marcial Pons.

Fradera, J. M. (2009b). La pàtria dels catalans: història, política, cultura. Barcelona: La Magrana.

Fuster, J. (1976). «Contra el nacionalisme», Diari Avui, 19 de mayo de 1976.

García de Cortázar, F. (2018). España, entre la rabia y la idea. Madrid: Alianza.

Greenfeld, L. (2005). Nacionalismo: cinco vías hacia la modernidad. Madrid: Centro de estudios políticos y constitucionales.

Greenfeld, L. (2017). Nacionalisme i democracia. Barcelona: CCCB.

Guibernau, M. (2009). Per un catalanisme cosmopolita. Barcelona: Angle. Lazare, B. (1898). Le nationalisme juif. París: Stock \&Flammarion.

Lladonosa, M. (2013). La construcció de la catalanitat: evolució de la concepció d'identitat social a Catalunya, 1860-1990. Lleida: Edicions de la Universitat de Lleida.

Lo Cascio, P. (2008). Nacionalisme i autogovern: Catalunya, 1980: 2003. Catarroja: Afers.

Lorenzo, Anselmo (1974). El proletariado militante. Madrid: Alianza.

Losurdo, D. (2014). La lucha de clases: una historia política y filosófica. Mataró: El Viejo Topo.

Marfany, J. Ll. (2017). Nacionalisme español i catalanitat (1789-1859): cap a una revisió de la Renaixença. Barcelona: Edicions 62.

Maurín, J. (1935). Hacia la segunda revolución: el fracaso de la república y la insurrección de octubre. Barcelona: Gráficos Alfa.

Mazzini, G. (2004). Pensamientos sobre la democracia en Europa y otros escritos. Madrid: Tecnos.

Nadal, J. (2018). Catalunya, mirall trencat. Barcelona: Pòrtic. 
Nin, A. (2008). Els moviments d'emancipació nacional: l'aspecte teòric i la solució pràctica de la qüestió. Barcelona: Base.

Núñez Seixas, X. M. (2010). Patriotas y demócratas: el discurso nacionalista español después de Franco. Madrid: Libros de la Catarata.

Núñez Seixas, X. M. (2018). Suspiros de España: el nacionalismo español, 1808-2018. Barcelona: Crítica.

Oltra, B., Mercadé, F. y Hernández, F. (1984). La ideología nacional catalana. Barcelona: Anagrama.

Ortega y Gasset, J. (2004). Obras completas. Volumen V. Madrid: Taurus y Fundación José Ortega y Gasset.

Ovejero, F. (2011). La trama estéril: izquierda y nacionalismo. Barcelona: Montesinos.

Ovejero, F. (2016). La seducción de la frontera: nacionalismo e izquierda reaccionaria. Vilassar de Dalt: Montesinos.

Oyón, J. L. y Romero, J. (eds.) (2017). Clase antes que nación: trabajadores, movimiento obrero y cuestión nacional en la Cataluña metropolitana, 1840-2017. Vilassar de Dalt: El Viejo Topo.

Prat de la Riba, E. (2007). La nacionalitat catalana. Barcelona: Escola d'Administració Pública de Catalunya.

Pujol, J. (1976). La immigració, problema i esperança de Catalunya. Barcelona: Nova Terra.

Pujol, J. (1976b). Una política per Catalunya. Barcelona: Nova Terra.

Pujol, J. (1988). Als joves de Catalunya. Barcelona: La Magrana.

Rigol, J. (1986). Poble i consciencia nacional. Barcelona: Edicions 62.

Riquer, B. de (2001). Escolta Espanya: la cuestión catalana en la época liberal. Madrid: Marcial Pons.

Riquer, B. de (2016). Anar de debò: els catalans i Espanya. Barcelona: Rosa dels Vents.

Rorty, R. (1999). Forjar nuestro país: el pensamiento de izquierdas en los Estados Unidos del siglo XX. Barcelona: Paidós.

Rovira i Virgili, A. (1999). El principi de les nacionalitats. Barcelona: Proa. 
Rubert de Ventós, X. (1999). Catalunya: de la identitat a la independència, Barcelona: Empúries.

Sánchez Cuenca, I. (2018). La confusión nacional: la democracia española ante la crisis catalana. Madrid: Los Libros de la Catarata.

Savater, F. (1985). Contra las patrias. Barcelona: Tusquets.

Savater, F. (2017). Contra el separatismo. Barcelona: Ariel.

Schnapper, D. (2001). La comunidad de los ciudadanos: acerca de la idea moderna de nación. Madrid: Alianza.

Smith, A. (2014). Origins of Catalan Nationalism, 1770-1898. Hampshire: Palgrave MacMillan.

Solé-Tura, J. (1970). Catalanismo y revolución burguesa. Madrid: Cuadernos para el Diálogo.

Taylor, Ch. (2014). «Nacionalismo y modernidad». En Glover, Jonathan et al. Naciones, identidad y conflicto: una reflexión sobre los imaginarios de los nacionalismos. Barcelona: Gedisa.

Termes, J. (1984). La immigració a Catalunya i altres estudis d'història del nacionalisme català. Barcelona: Empúries.

Termes, J.(1999). Les arrels populars del catalanisme. Barcelona:Empúries.

Termes, J. (2007). La catalanitat obrera: la República catalana, l'Estatut de 1932 i el moviment obrer. Barcelona: Afers.

Termes, J. y Colomines, A. (2003). Patriotes i resistents: història del primer catalanisme. Barcelona: Base.

Torra, Q. (2011). Honorables: cartes a la pàtria perduda. Barcelona: A Contra Vent.

Ucellay Da Cal, E. (1982). La Catalunya populista: imatge, cultura i política en l'etapa republicana. Barcelona: La Magrana.

Ucellay Da Cal, E.(2018). Breve historia del separatismo catalán. Barcelona: Editorial B.

Ucellay Da Cal, E., González i Vilalta, A. y Núñez Seixas, X. M..Catalunya davant del feixisme (1919-2018). Maçanet de la Selva: Gregal.

Uriarte, E. (2003). España, patriotismo y nación. Madrid: Espasa Calpe. 
Vandellós, J. (1935). Catalunya, poble decadent. Barcelona: Biblioteca Catalana d'Autors Independents.

Vélez-Pelligrini, L. (2003). El estilo populista: orígenes, auge y declive del pujolismo. Barcelona: el Viejo Topo.

Vergés, J. (2014). La nació necessària: llengua, secessió i democracia. Barcelona: Angle.

Vicens Vives, J. (1999). Notícia de Catalunya. Barcelona: Columna.

Viroli, M. (1997). Por amor a la patria: un ensayo sobre el patriotismo y el nacionalismo. Madrid: Acento.

VVAA (2017). Terra de ningú: perspectives feministes sobre la independència. Barcelona: Gatamaula.

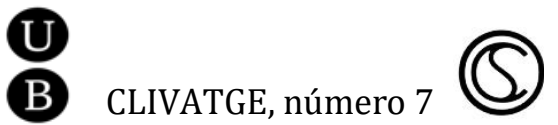

